\title{
Modelling the Maritime Cultural Landscape of the Costiera Amalfitana: The First Three Seasons of Research (2016-2018)
}

Matthew Harpster, Athena Trakadas, Elif Denel, Vincenzo Capriglione, Carlotta Lucarini, Marie Meranda, Mattia Morselli, Robyn Pelling, Iain Bennett, Chiara Zazzaro, Özge Demirci, Carlo Donadio, Luigi Ferranti, Corrado Stanislao, Luca Zavagno \& Paolo Pecci

To cite this article: Matthew Harpster, Athena Trakadas, Elif Denel, Vincenzo Capriglione, Carlotta Lucarini, Marie Meranda, Mattia Morselli, Robyn Pelling, lain Bennett, Chiara Zazzaro, Özge Demirci, Carlo Donadio, Luigi Ferranti, Corrado Stanislao, Luca Zavagno \& Paolo Pecci (2021) Modelling the Maritime Cultural Landscape of the Costiera Amalfitana: The First Three Seasons of Research (2016-2018), International Journal of Nautical Archaeology, 50:1, 63-75, DOI: $10.1080 / 10572414.2021 .1947117$

To link to this article: https://doi.org/10.1080/10572414.2021.1947117

Published online: 10 Aug 2021.

Submit your article to this journal $\longleftarrow$

Цll Article views: 27 


\title{
Modelling the Maritime Cultural Landscape of the Costiera Amalfitana: The First Three Seasons of Research (2016-2018)
}

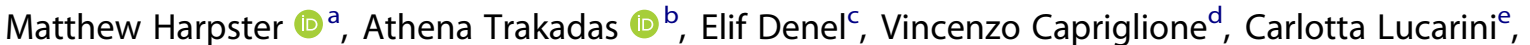

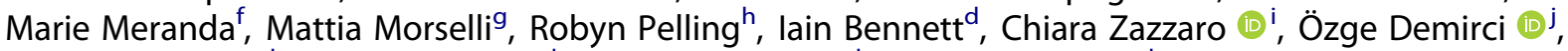

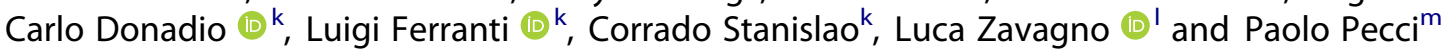

\begin{abstract}
${ }^{a}$ Department of Archaeology and History of Art, Koç University, Istanbul, Turkey; ${ }^{b}$ National Museum of Denmark, Copenhagen, Denmark; 'American Research Institute Turkey, Ankara, Turkey; ${ }^{\mathrm{C}}$ Independent Researcher, Archaeologist; ${ }^{\mathrm{e}}$ University of Murcia, Murcia, Spain; fDepartment of Anthropology, University of South Florida, St Petersburg, USA; ${ }^{9}$ Scuola di Specializzazione in Beni Archeologi, University Suor Orsola Benincasa, Naples, Italy; 'Wessex Archaeology, Salisbury, England; 'University of Naples 'L'Orientale', Naples, Italy; ${ }^{j}$ Groningen Institute of Archaeology, University of Groningen, Groningen, Netherlands; ${ }^{k}$ Department of Earth Sciences, University of Naples Federico

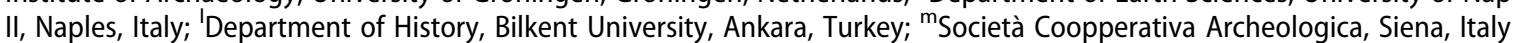

\section{ABSTRACT}

Human activity along the Amalfi coastline in Italy has been tied to the sea for millennia - for sustenance, migration, trade, warfare, and leisure. As a result, this region has an equally rich and extensive maritime cultural landscape composed of tangible and intangible elements. In 2016, a multi-disciplinary project began efforts to model and to understand changes within this landscape, and this essay presents the preliminary results of our first three seasons of work. Some efforts, such as the documentation of maritime cultural heritage in local museums, archival work, and geomorphological research proceeded smoothly. Unexpectedly, however, little material from the pre-modern era was found under water, adding questions to this study that future work in the Marine Protected Area west of Positano may answer.

\section{KEYWORDS}

Maritime landscape; Italy; Amalfi; underwater survey; geomorphology; history

\section{Introduction}

Since 2016, a multi-disciplinary team has been synthesizing archaeological, textual, and geomorphological data to model and to understand how the maritime landscape between Salerno and Punta Campanella, Italy, has changed over time. Over three seasons, the project has been conducted under the auspices of the Soprintendenza Archeologia, Belle Arti e Paesaggio per le Province di Salerno e Avellino, and led by Koç University. An international team of researchers have participated as well, with individuals from Italy, the United Kingdom, the United States, Turkey, and Denmark. This article introduces the project and its methodologies, the research agenda incorporating a diachronic perspective, preliminary results of the first three seasons, and the project's future plans.

\section{Geographic and Historical Context}

In a variety of ways, the characteristics of the peninsular coastline between Salerno and Punta Campanella, Italy, make it an ideal laboratory for studying maritime landscapes (Figure 1). The coarse topography and narrow river valleys limit the dispersal of settlements and their inhabitants, so the coastline and adjacent waters become natural outlets for activities and communication. In addition, the combination of the coastal settlements' terrestrial isolation and maritime engagement makes them virtual islands, much as the Sahara has isolated Cyrenaica and Morocco from the rest of the African continent (Shaw, 2003, p. 98). Similarly, without extensive terracing of the surrounding hills, maritime activity is also the most convenient form of subsistence. Fishing and other forms of aquaculture, ferrying of people and goods, local and long-distance trade, and all of the associated industries, are equally viable means to sustain individuals and communities within this environment. ${ }^{1}$ Tangible and intangible social constructs, such as place names, monuments and memorials, the spatial organization of ports, and the demarcation of 'commercial', 'public', and 'protected' waters are also emblematic of this relationship between people and the sea. The Sanctuary of the Blessed Virgin Mary overlooking the waters between Amalfi and Maiori, or the smaller Abbey of Saint Peter near Crapolla, incorporate multiple perceptions of this space as well. While each might convey a sacred message to seafarers passing by, they also act as waypoints or landmarks. Private yachts, kayaking, and scuba diving, and the spaces they operate within, are another layer of this landscape, as are the coastal grottoes and private beaches. More broadly, the sea is an almost unavoidable part of this environment. Visually, 


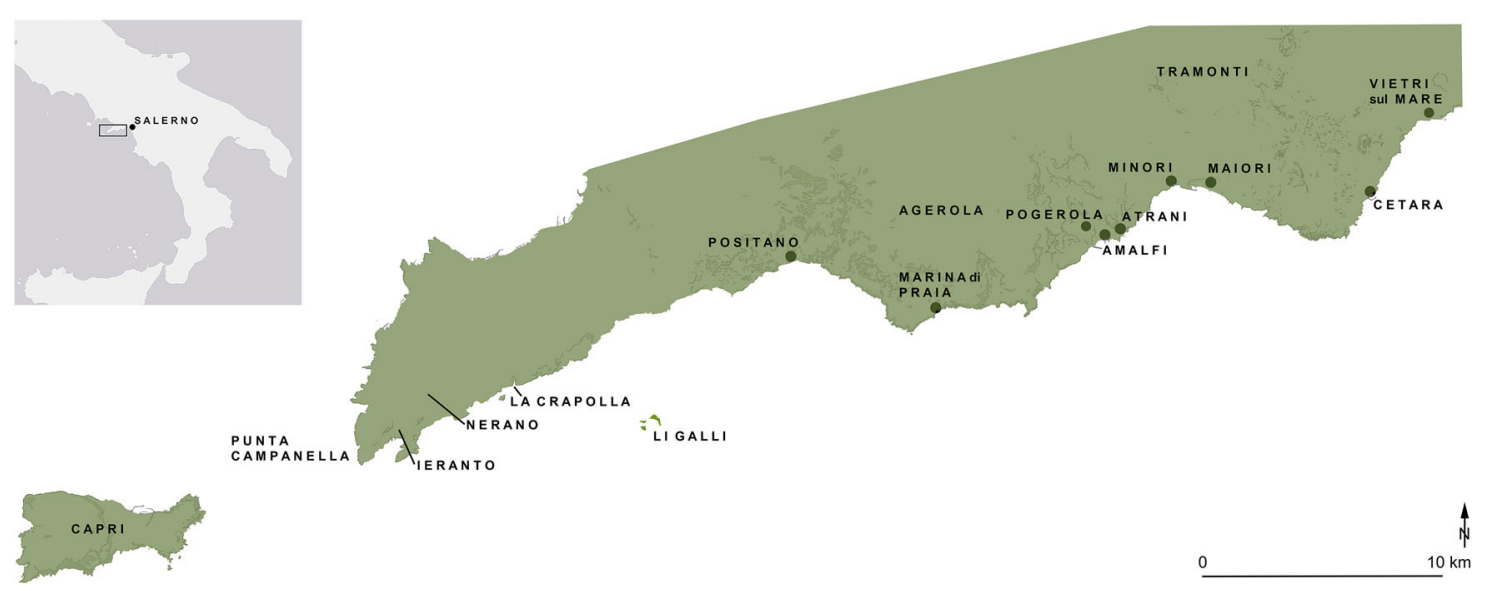

Figure 1. Map of the peninsula (Matthew Harpster)

there are few locations on the southern side of the peninsula from which the water cannot be seen, and the sea has been an integral element of depictions of the region for centuries (Fino, 1995). The steep topography, too, favours routes of movement directed towards the sea and upon its surface.

The area is also rich historically; this coastline and the surrounding region has been inhabited since the prehistoric era. Hand axes, scrapers, and denticulate tools of the Acheulean industry from the Lower and Middle Palaeolithic were found on Capri, while later Mousterian lithics and faunal remains of deer, bear, and ibex around the small bays at Nerano and Ieranto nearby attest to additional human occupation of the area (Figure 1) (Albore Livadie, 1990). During the Upper Palaeolithic, evidence indicates that more of the coastline was inhabited while, due to the lower sea-levels during the last glaciation, the adjacent seabed was exposed and likely exploited as well (Albore Livadie, 1990). Human activity in the transition to the Early Holocene, prior to 12,000 $\mathrm{BP}$, is attested by remnants of Epigravettian toolkits, contemporaneous faunal remains, and occupation levels characterized by deep shellfish layers found in three caves near Positano. Similarly, 43 Neolithic-era tools were found in the small grotto of Saint Andrea near Amalfi (Radmilli \& Tongiorgi, 1958; Ronchitelli, 1996, p. 3; Tozzi, 1976, pp. 33-49). From the Bronze and Iron Ages, scattered finds such as decorated and plain pottery, ash layers from cooking fires, as well as necropoli were found in Nerano, Positano, and the communes of Agerola and Tramonti (Albore Livadie, 1990, p. 33, 2007, pp. 162-163; Camardo, 2008). Activity to the north and south in Pompeii, Herculaneum, and Paestum during the Iron Age also continued into the Archaic era (Pappalardo \& Ciardiello, 2005).

Archaeological evidence indicates that a temple to Athena was built on Punta Campanella in the 6th century $\mathrm{BC}$, and a nearby Oscan inscription suggests that the use of the area continued for another four centuries (Greco, 1992, p. 166; Guzzo, 1992; Pollone \& Romano, 2015, p. 274). In addition, red and black- figure pottery, as well as some bronze statuettes, were recovered from Archaic era tombs in Vietri sul Mare in 1968 (D’Agostino, 1968).

The Late Roman Republican and early Imperial periods were particularly rich, marked by a more stable and extensive occupation of this coast, likely tied to the growth of urban and semi-urban centres in Baiae, Herculaneum, and Pompeii to the north, and Salernum and Paestum to the east and south. Villae maritimae were built in the coves of Minori, Positano, and possibly Amalfi, and some smaller villae appeared on the islands of Li Galli and Isca, possibly linked to the Roman-era warehouses in the tiny bay at Crapolla (Bencivenga et al., 1980; Jacobelli, 2017; Johannowsky et al., 1986; Mangieri, 1988; Mingazzini \& Pfister, 1946; Russo, 2014). In addition to the appearance of the Emperor Tiberius' Villa Jovis on Capri, associated structures were also built on Punta Campanella (Mingazzini \& Pfister, 1946). There may have been a private residence during this era in Vietri sul Mare as well, due to the remnants of a thermal bath and associated finds, and villae rusticae found in and near modern Salerno and Tramonti were likely built and used during these centuries too (Camardo, 2008; Iannelli, 1991; Iannelli, 2011a, 2011b; Romito, 1986).

Local activity diminished following the eruption of Vesuvius in AD 79, but did not disappear. Among the coins found in the excavation of Minori's villa maritima, 76 were minted in the centuries following the eruption (Mangieri, 1988, pp. 169-185). Equally, excavations in Salerno have uncovered villae rusticae used from the 3rd to 5th centuries. Within the following 200 years, however, the general pace of life appears to have accelerated. Letters of Pope Gregory the Great from the late 6 th or early 7 th century suggest that the settlement at Amalfi was considered a civitas by this time, and the Codex epistolaris Carolinus refers to the Amalfitan community playing a larger role in the political and economic life of southern Italy between 8th and early 9th century (Espelo, 2014; Migne, 1849, p. 3, 6, XXIII). For the Lombards based 
in Benevento, Amalfi was a target to be conquered in 786, while in 812 the Amalfitans answered the Papal request for naval help against Arab pirates sacking the south Tyrrhenian Sea (Monumenta Carolina, Codex Carolinus 82, Leonis epistolae 6, 323).

During this period the adjacent settlement of Atrani increased in size and importance and, by the end of the 9th century, Amalfi and the nearby cities gained their autonomy from Naples, leading to more prosperity over the following two centuries (Arthur, 1991, p. 762, 777; Kreutz, 1996, pp. 80-81). Indeed, as their share in Mediterranean trade grew in the 11th century, the Amalfitans settled a small quarter in Constantinople just as the bronze doors of Amalfi's Duomo were fashioned in Constantinople and installed soon afterwards (Balard, 1976, p. 87, 95; Bergman, 1991, p. 430; Jacoby, 2014, p. 91). Similarly, the wealthy merchant Urso Castellomata commissioned a private family church of S. Michele Arcangelo in nearby Pogerola near the end of the 12th century (Bergman, 1991). Under the reign of Charles d'Anjou in the 14th century, the peninsula was marked by a series of cylindrical defensive towers; some were modified in the 16th century into square towers still evident today (Pollone \& Romano, 2015).

In addition to this extensive historical record, another reason to study this coastal region as a maritime landscape is the relatively brief history of maritime archaeological work in the area. ${ }^{2}$ Likely prompted by similar activity at the 1st-century BC site at Albenga in 1950 and 1957, nearby work at Baiae in 1957, Spargi in 1958, and the creation of the Centro Studi Archeologia Subacquea (CSAS) in the same year, maritime archaeological work in the Amalfi region began in the 1960s. This work primarily focused on two areas. First was the zone between Marina di Praia, Positano, and the Li Galli islands, and second was the area of Amalfi's harbour. Soprintendenza records in Salerno indicate that in these years an increasing number of divers reported amphoras and other types of pottery on the seabed in this first area; at least 17 of the amphoras in the villa maritima museum in Minori were found on this seabed in 1960 (Romito, 1988, p. 142). Additional complete and partial amphoras found in this region were added to the museum's collection by 1993 (Deposito Minori, pp. 69-70). Similarly, 14 of the lead anchor elements in the museum were gathered from the seafloor in 1963 and 1964 in a project directed by Robert Lover, also between Positano and the Li Galli islands (Figure 1) (Deposito Minori, pp. 65-68).

Efforts in Amalfi's harbour appear to have begun by 1970. In that year Plinio Amendola, working with Guido Picchetti at il Centro Sub di Sorrento, investigated rumours of the city's submerged remains in the harbour area. In addition to a few terracotta and ceramic fragments, the team found a submerged feature approximately $6 \mathrm{~m}$ deep and $50 \mathrm{~m}$ from shore, in front of the pre-modern outlet of the Canneto
River. Picchetti and his team proposed that this submerged structure was part of the medieval city's original sea walls (Picchetti, 1970, p. 157).

Robert Bergman and Harold Edgerton conducted remote-sensing work in Amalfi's harbour in 1979, and their results appear to contradict these conclusions. With Edgerton's sidescan sonar and sub-bottom profiler, Bergman's team was searching for evidence of Amalfi sommersa, a theory that the southern portion of the city had been toppled in a cataclysm between the 12th and the 14th century and the only remnants were under water (Bergman, 1979). Picchetti's interpretation of the submerged feature as the foundation of a sea wall, for example, was one manifestation of this perspective. Bergman and his team challenged such interpretations as they found no evidence of an obvious architectural infrastructure now submerged in the seafloor. They did find two anomalies, however. In the eastern portion of the harbour they found a concentration of stones approximately $250 \mathrm{~m}$ in diameter and in water $10 \mathrm{~m}$ deep. The second anomaly was a concentration of stones and boulders forming a rough arc - likely the same feature identified by Picchetti in 1970 (Bergman, 1979). Bergman and his team, noting the anomaly's location immediately opposite the outlet of the river, suggested that this is a natural accumulation of debris. A study in 2004 with a SEISTEC sub-bottom profiler, however, supports an alternative; that this is a manmade feature, and may be the 13th-century pier built by Cardinal Pietro Capuano (Violante et al., 2004).

Underwater research elsewhere along this coastline has been rare. Equally, little seems to have occurred in recent decades in these two locations or nearby. Parker's, 1992 catalogue only mentions two sites near the Li Galli islands and Praiano, both roughly from the Roman Imperial era (Parker, 1992: \#433, 899). Rota's 1996 discussion of maritime archaeological work in this region mentions these sites, and adds a submerged structure near Vietri sul Mare, possibly of opus reticulatum (Rota, 1996, p. 255). Rota suggests that more work and potential was to the south near Paestum, Punta Licosa, Palinuro, and San Marco di Castellabate (Rota, 1996, p. 256). The Archeomar Project documented two sites in this region after the turn of the millennium. Begun in 2004 by MiBACT (Ministero dei Beni Attività Culturali del Turismo), this project first focused on Campania, Calabria, Puglia, and Basilicata in an effort to generate a national inventory of submerged heritage. Of the 763 sites identified in these four regions, two from the Roman or Late Roman era are along this coastline in deep water near the island of Capri (Anon., 2006, p. 9; Recchia, 2004, pp. 134-137). Most recently, in 2013, Paolo Pecci finished his research on a submerged structure in Punta Fuenti between Vietri and Cetara, what may be a pila or Roman-era mooring stone, and 


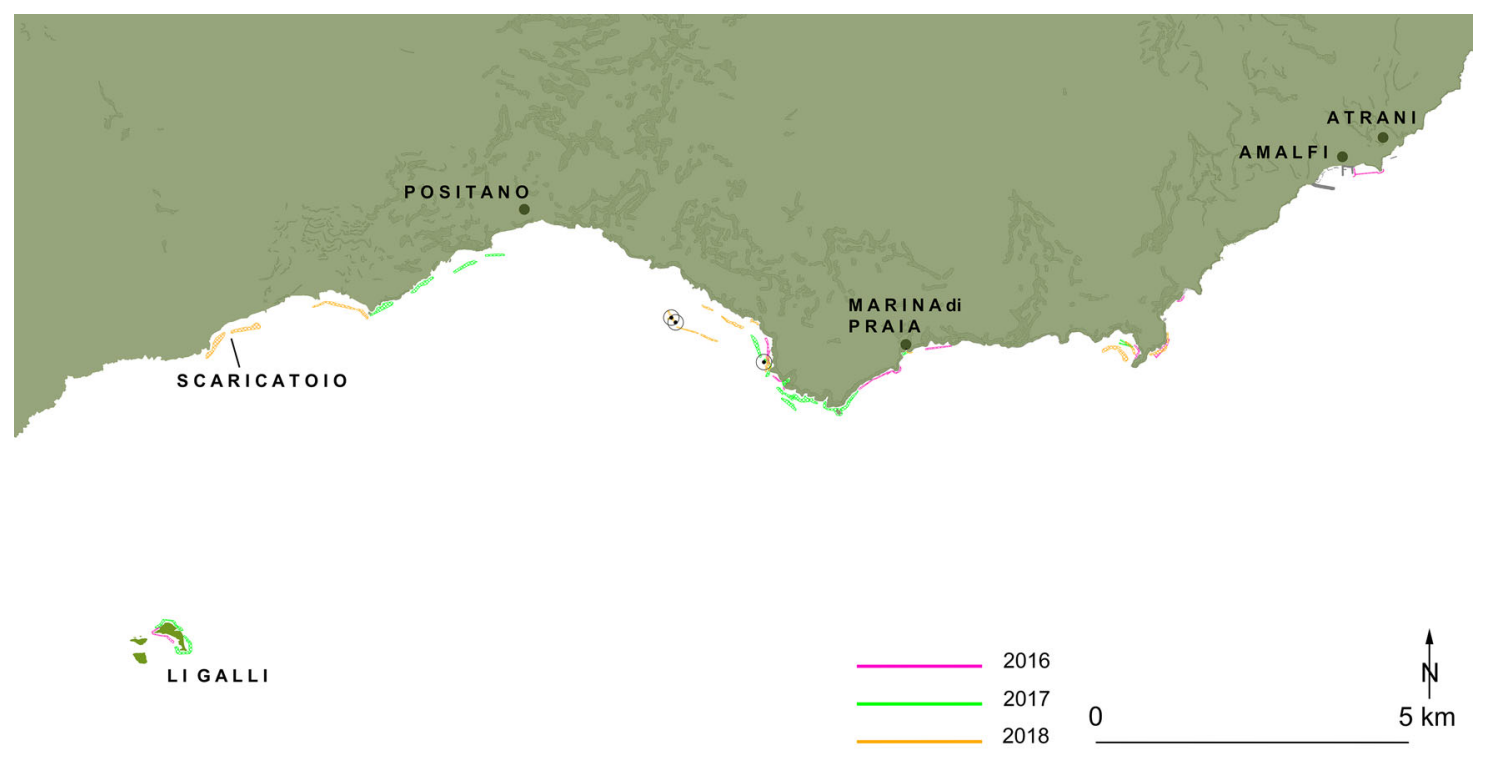

Figure 2. Detail map of the survey area between the Li Galli islands to the west and Amalfi to the east. (Matthew Harpster).

argues that this represents a more complex harbour structure in the area. This is likely the same item mentioned by Rota in 1996.

Conducting additional archaeological surveys along the coast and under water, therefore, could add to this collection of work. The seafloor off Positano that yielded material in the past could be assessed for its present archaeological potential, whereas other efforts could focus on portions of the seabed that had not been previously surveyed systematically. Moreover, the results can contribute to the growing corpus of submerged heritage in the region, and inform models of the region's maritime landscape.

\section{Research Campaigns, 2016-2018}

By 2016 and the first season of fieldwork, this coastline contained a great deal of research potential, both for investigations to understand changes in this maritime landscape in the past, and to generate methodologies applicable elsewhere. Pursuing this potential has required a variety of disciplines. In addition to archaeological surveys under water with dive teams, this project has incorporated manual and digital documentation efforts in local museums, ethnographic work, archival research in Salerno and Amalfi, coastal geomorphological survey, and various analytical approaches with Geographic Information Systems. As will be evident from this article, the first three seasons of work have focused on material culture and the natural environment; more intangible elements of this inhabited landscape will be emphasized in future years.

\section{Archaeological Surveys Under Water}

In three seasons from 2016 to 2018, archaeologists worked with Gaetano Milano at Centro Sub Costiera
Amalfitana in Marina di Praia and completed 63 dives during 31 days in the field. Conducting swim-line surveys from a surface support vessel, the group systematically surveyed approximately $21 \mathrm{~km}$ of the seabed between the Li Galli islands to the west and the Bay of Amalfi to the east (Figure 2). During these three seasons, 12 of the dives were over $20 \mathrm{~m}$ deep. Resulting from these surveys, however, are only three sites of archaeological interest on the seafloor (Figure 3). Found in 2016, the team identified one site with a handful of ceramic body sherds in approximately $20 \mathrm{~m}$ of water, just to the west of Torre di Grado (Figure 4). As per our survey permit, these items were left in situ on the seafloor but preliminarily classified as fragments of medieval ceramics; more precise classifications are difficult without further study. Two more sites were found $1.6 \mathrm{~km}$ to the northwest in 2018 (Figure 3), containing additional ceramic body sherds. In particular, one neck and shoulder fragment, and a second found nearby, had similar characteristics. These items are presently presumed to be similar in date to the finds from the first site.

After surveying this area for three seasons, the lack of coherent, well-preserved sites in water less than $30 \mathrm{~m}$ deep along this coastline is not particularly surprising. Such sites would either have been found, documented, and excavated previously, or they could have been looted. A surprising phenomenon, however, is the near-complete absence of poorly preserved sites, or even a mixed scatter of ceramic fragments distributed across the seabed, when there is a fairly constant occupation of the land nearby.

As a result, an unexpected addendum to this project has become explaining this phenomenon, and we are presently investigating four possibilities. First, in some areas, the coarse cliffs that characterize this environment continue to descend nearly vertically below sealevel. Presumably, material lost near these features 


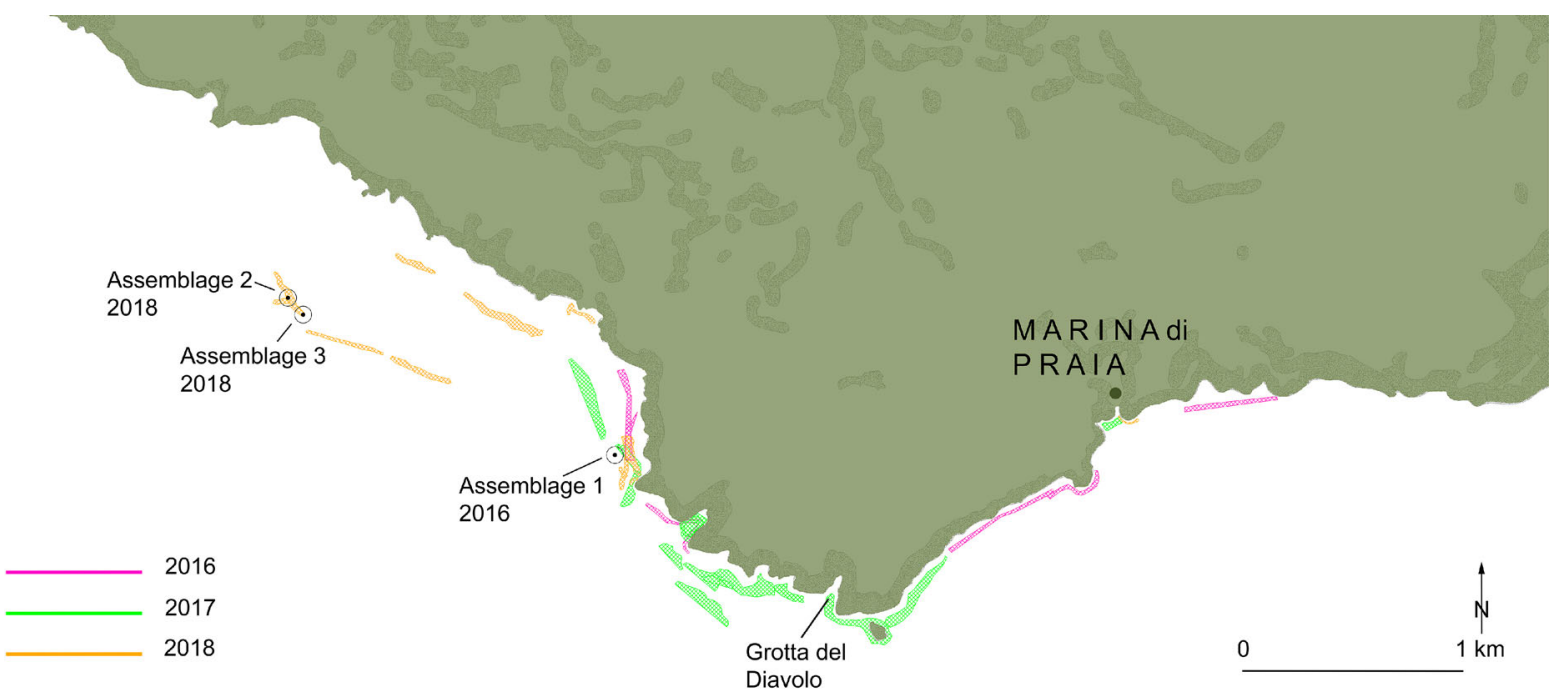

Figure 3. Survey area near Marina di Praia. (Matthew Harpster).
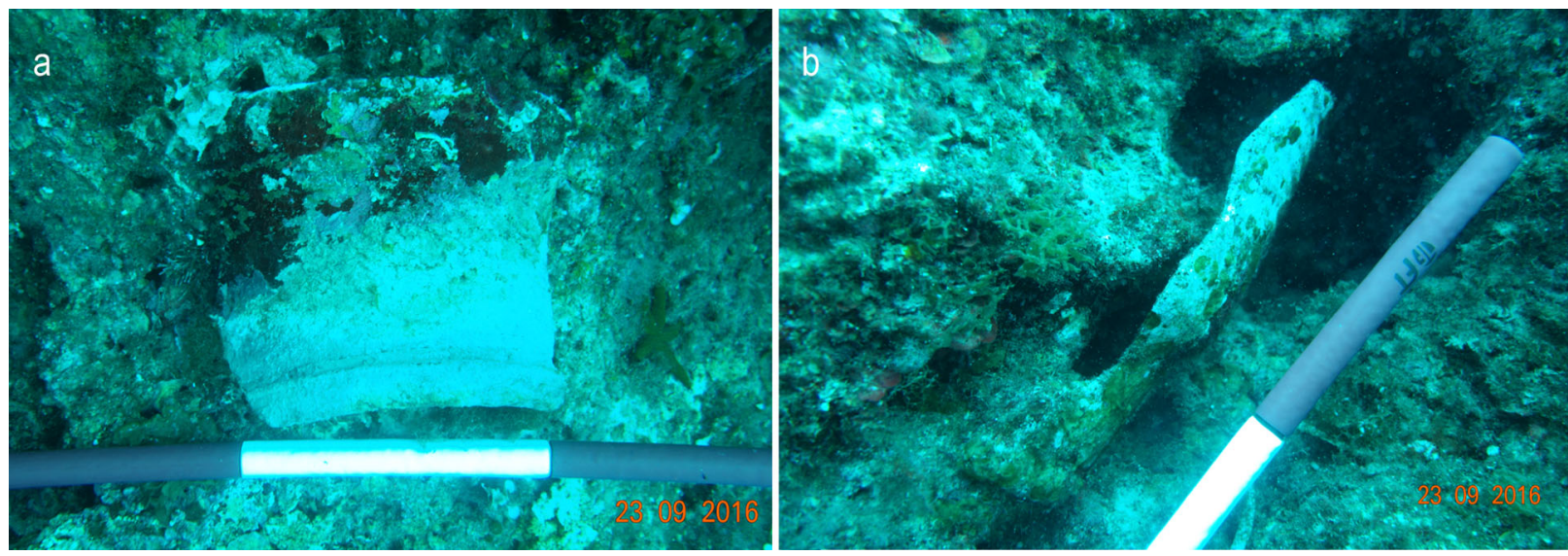

Figure 4. (a) and (b) Fragmentary ceramics found in 2016. The scale is in $10 \mathrm{~cm}$ increments. (Matthew Harpster).

sunk immediately to depths beyond our present methodology or, after deposition at shallower depths, slowly moved to deeper regions. Notably, the seafloor between Positano, Li Galli, and Praiano where items have been found is relatively flat. Second is likely the eruption of Vesuvius in AD 79. Between 0.10 and $0.20 \mathrm{~m}$ of volcanic ash was deposited along this portion of the peninsula following the eruption (Macedonio et al., 2008, p. 373). Subsequent rainfall created a slurry of ash, water, and soil, however, that flowed downhill and deposited a dense layer on the seafloor (see Budillon et al., 2006, p. 842; core C836 and Insinga et al., 2008, p. 183 , core $\mathrm{tS} 2) .{ }^{3}$ Like the villa maritima at Positano, items on the seabed would have been buried by this volcanic layer. Looting may be a factor as well, yet this activity would not be solely responsible for this virtual absence of archaeological material. Even if poorly preserved or relatively undiagnostic, some archaeological items would still remain scattered across the seafloor. The fourth possibility is the effort following World War II to revitalize the infrastructure along this coastline, in particular the coastal road uniting the harbour cities. For example, bedrock and soil from this work was deposited on the seabed at Grotta del Diavolo and decreased the depth from 30 to $7 \mathrm{~m}$ (Figure 3). A similar deposition of debris occurred west of Punta Germano, at a location now known as Scaricatoio, 'the dumping place' (Figure 2) (pers. comm., Gaetano Milano, September 2017 and 2018). Like the Vesuvian deposition, this modern accumulation of material could obscure assemblages on the seafloor.

To test these four hypotheses, future work is planned in the marine protected area of the coastline west of Positano. This area lacks a coastal road like that between Positano and Salerno, has distinctly fewer coastal settlements, and fishing, boating, and diving is limited by present regulations. The deposition from Vesuvius' eruption in AD 79 was smaller as well (Macedonio et al., 2008, p. 373). As a result, it lacks many of the conditions that may be impacting the preservation of material but is still surrounded by prehistoric and historic sites. Our surveys in this area will be able to test these presumptions while investigating the efficacy of the regulations that limit activity as well. 


\section{Geomorphological Investigations}

As this project focuses on the changing inhabitation of this coastline and the sea, models of the physical changes of this coastline are particularly valuable. Previous studies conducted along the coastal areas of Campania, therefore, can provide a methodological framework for these efforts. For example, in Salerno and Naples samples from boreholes in coastal plains documented the existence of ancient marine deposits below the present sea-level, and paleo-sea notches associated with local fossiliferous sediments have been mapped along coastal promontories including the Amalfi coastline (Brancaccio et al., 1978; Cinque \& Romano, 1990; Ferranti, 2007; Ferranti \& Antonioli, 2007; Riccio et al., 2001; Romano et al., 1994; Santangelo et al., 2017). These data have been used to reconstruct these changing coastlines during the Pleistocene and Holocene eras (Brancaccio et al., 1991; Santangelo et al., 2017). Similarly, boreholes at Mondragone, to the north, also collected sediments for granulometric and morphometric analyses, and the analysis of any microfossils, while test pits revealed the lithological-archaeological stratigraphic sequence (Aiello et al., 2018). Underwater work in Sinuessa, in contrast, employed sidescan sonar to map seabed topography, while grain-size and texture analysis of sediment samples from the beach and seabed aided in reconstructing the area's paleoenvironment (Pennetta et al., 2016).

Many of these methods are ideally suited for flat, coastal plains, however, they cannot be applied in our survey area due to the sheer cliffs, rough sea-beds, and coarse sedimentary input. Moreover, only a handful of studies have been conducted at a few locations off the Amalfi coastline (for example Cinque \& Putignano, 1992; De Pippo et al., 1998). Although these provided a great deal of local detail, they encountered difficulty in dating the retrieved evidence of past sea-levels. More shallow-depth boreholes may be possible in the future, but such sampling could only be done at selected locations offshore as the region's few coastal plains are heavily inhabited. Similarly, no destructive sampling may be completed in the marine protected area between Positano and Punta Campanella.

An advantage, however, is that modelling changes in the relative sea-level along the Amalfi coastline is somewhat easier than elsewhere in Campania. Although studies have documented geological subsidence of the coastal plains and bays at Naples and Salerno as a result of tectonic and volcano-tectonic downlift, sediment compaction, and anthropic influences, research attests that this peninsula and Capri have been fairly stable geologically since at least the last interglacial, approximately 125,000 years BP (Brancaccio et al., 1991; Ferranti, 2007; Ferranti et al., 2006; Ferranti \& Antonioli, 2007; Santangelo et al., 2017). Thus, any onshore and offshore signs of changing sea-levels must result primarily from variations in global sea-level due to climatic fluctuations.

Our present documentation, gathered from surface sampling of seabed sediments and analysis of submerged paleo-sea notches, is beginning to yield results. Although no biogenic markers useful for radiometric dating, such as Lithodomus sp., were identified in 2018, two submerged paleo-sea notches were found. One, near Gavitella, is approximately $12 \mathrm{~m}$ deep, and may be associated with two different dates. First, the notch may have been formed approximately 100,000 80,000 years ago during a secondary peak (MIS 5.3 or MIS 5.1) of the last interglacial (for example Waelbroeck et al., 2002). Paleo-sea-levels at a similar depth have been observed at Capo Palinuro approximately $90 \mathrm{~km}$ to the south and are represented by now-submerged caves with channels incised by marine abrasion in their floors, and have been attributed to MIS 5.3-5.1 highstands (Antonioli et al., 1994, pp. 252-256). Second, this depth also associates well with the global sea-level suggested for an older interglacial peak (MIS 7a) which occurred approximately 230,000 years ago. If confirmed by further analyses, this latter date implies a much longer period of geological stability for the rocky coasts of the peninsula (Cinque \& Romano, 1990).

The other sea-notch was found to the southwest of Marina di Praia in 2018 approximately $1.5 \mathrm{~m}$ deep (Figure 5). This shallower notch is most likely related to a recent sea-level change during the Late Holocene. In particular, based on the glacio-eustatic sea-level curves for Italy, it likely formed between 2000 and 2500 years BP (Lambeck et al., 2011).

Combined with other notches previously identified by other teams and roughly dated to 125,000 years BP (MIS 5.5), a model of relative change in the sea-level in this region is emerging. If the sea-notch at Gavitella is associated with MIS 7a, then the relative sea-level was approximately $12 \mathrm{~m}$ below the present levels around 230,000 years $\mathrm{BP}$, then, during the penultimate interglacial $(125,000$ years BP) it stood much higher - approximately $8 \mathrm{~m}$ above present. Next, it dropped dramatically during the last ice age and possibly generated the incised channels at Capo Palinuro; if the notch at Gavitella is of a younger date, then it was formed during this era as well. As the Holocene has progressed, the sea-level has continued to rise but left its imprint 2000-2500 years BP during a relative sea-level stasis. Nevertheless, much more geological investigation and analysis is necessary to refine our model of relative sea-levels in more recent historical eras.

\section{Documentation in the Villa Maritima Museum, Minori}

In parallel with the archaeological and geomorphological surveys under water, related work has been proceeding on land. First is the completion of our efforts to record 


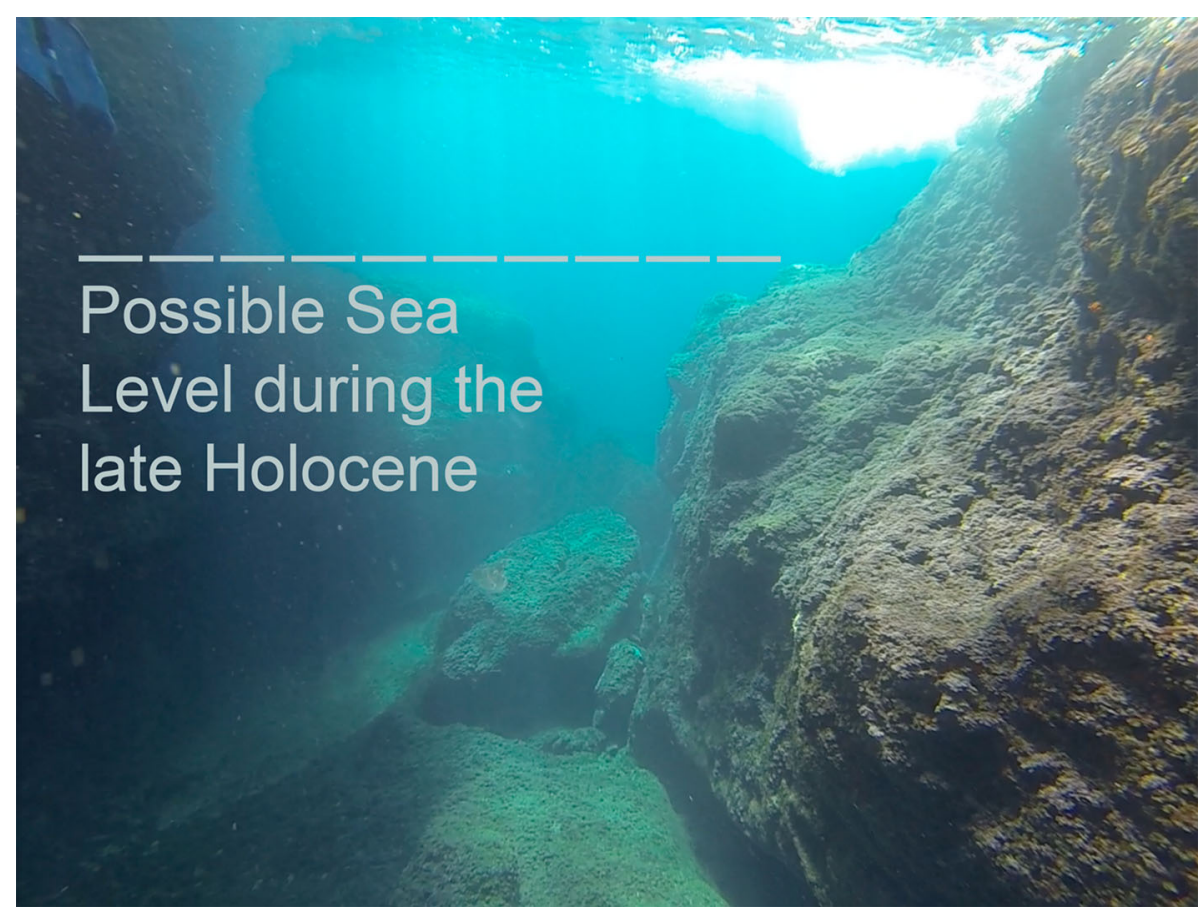

Figure 5. Geological sea-notch in the coastal bedrock southwest of Marina di Praia (Carlo Donadio)

the amphoras in the villa maritima museum in Minori that had been recovered previously from the seafloor (Figure 6). This is not the first time this effort has been attempted, as Matilde Romito - a former Soprintendente in Salerno - published preliminary studies on 17 of the amphoras in the museum in 1988 and 1989. After three seasons of work, the documentation of all 44 amphoras in the museum's collection is finished; of these, 39 were found off the peninsula's southern coast.

Within this collection, 20 amphoras have been tentatively identified, and presently examples from the western-Mediterranean appear to predominate. A much more thorough study is underway, but six of the amphoras may be variants of Dressel 2-4 types produced in Italy and North Africa, and three other amphoras in the collection are likely the Keay and Africana Grande types also from North Africa. ${ }^{4}$ There appear to be three Graeco-Italic examples, one of which is a Type $\mathrm{Vb}$ piccolo, a Dressel 1 and Dressel 21-22 from Campania, a Lamboglia 2 from the Adriatic, and an Almagro 54 and Beltran 2A from Spain. ${ }^{5}$ More broadly, however, a seventh Dressel 2-4 may be a variant from Kos, and there is an Égyptienne Bitronconique 3 from the Nile region. ${ }^{6}$ Lastly, at least one Late Roman I amphora is in the collection, possibly made in the eastern Mediterranean, although its similarities to those made in nearby Misenum or Ischia are notable. ${ }^{7}$

Chronologically, the collection appears to begin in the 4th or 3rd century BC, with the Graeco-Italic Type $\mathrm{Vb}$ piccolo, and finishes by the 7th or 8th century $\mathrm{AD}$ with the Late Roman example. Paralleling this chronological scope is an equally broad geographic range, seemingly from Egypt to Spain, suggesting that this coastline was part of a diverse network of activity across the Mediterranean. Moreover, this collection of amphoras also suggests that activity in this area did not necessarily cease following the eruption of Vesuvius in AD 79. Although the scale or volume of activity represented by this small dataset cannot be determined reliably, the simple presence of amphoras from Spain and North Africa dating between the 1st and 7th centuries $\mathrm{AD}$ suggests that life in this region continued even if the peninsula's villae were no longer in use. Similar evidence is found in the numismatic record of the villa itself. Mangieri's analysis of 78 coins from the villa excavations indicates that 76 were minted between the 1st and 4th centuries $\mathrm{AD} ; 30$ examples date from the 4th century alone (Mangieri, 1988, pp. 169-185). Ongoing studies in Salerno also suggest activity at a sub-urban villa during the 3rd century, as well as at the Trotula de Ruggiero site in the 4th or 5th centuries (Iannelli, 2011c, 2011d). Other work closer to Naples also suggests the ongoing occupation of some structures, agricultural practices on the slopes of Vesuvius, and grape cultivation and wine production prior to the middle of the 5th century (Allevato et al., 2012, p. 405; Inoue et al., 2009, p. 51; Mastrolorenzo et al., 2002, p. 22). The eruption of Vesuvius in $\mathrm{AD} 79$ curtailed life along this coastline, but the archaeological record suggests that any abandonment was neither complete nor long-lived.

\section{Historical and Archival Work, and Built Heritage}

As the city and Duchy of Amalfi has been the subject of numerous books and studies, this project's efforts in local libraries and archives do not focus on writing 

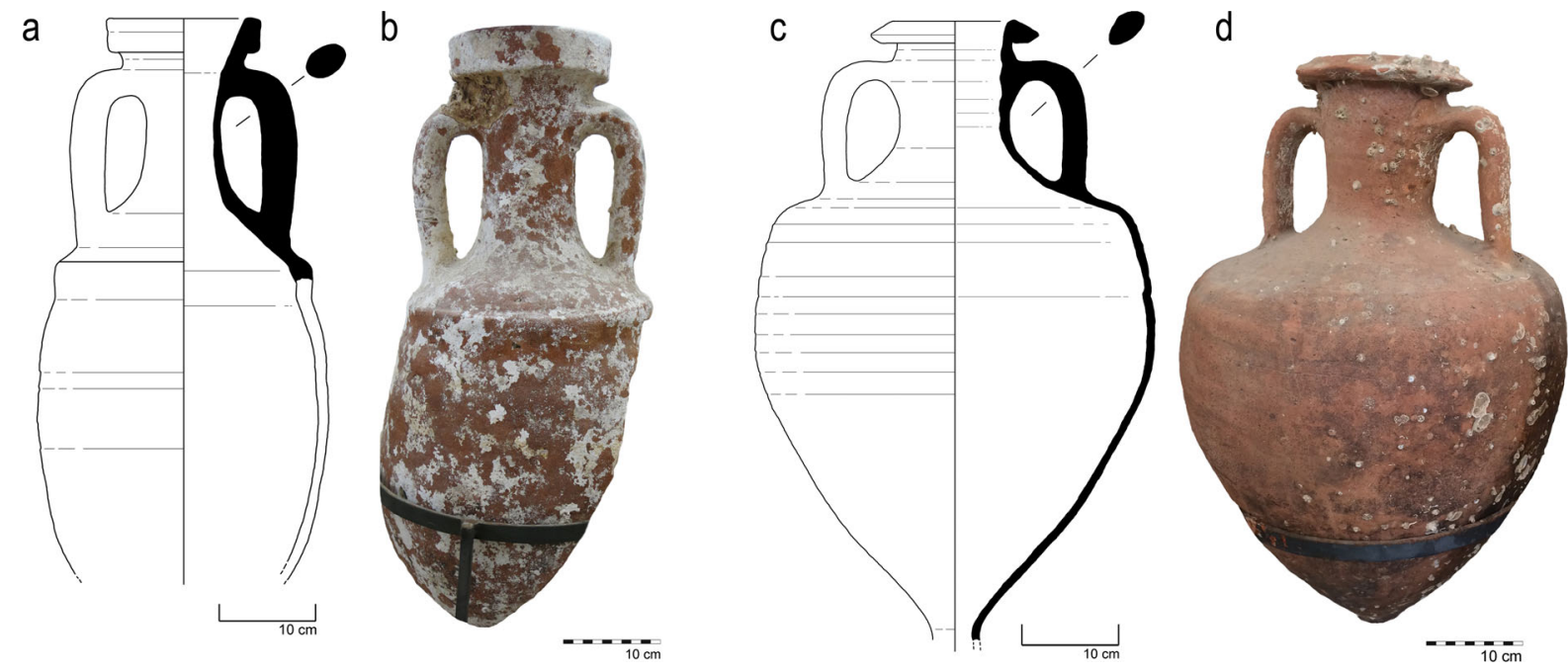

Figure 6. Amphoras in the Minori museum collection: possible Dressel I type (a) drawing (Elif Denel and Athena Trakadas); (b) photo (Athena Trakadas); Graeco-Italic Vb piccolo type (c) drawing (Elif Denel and Athena Trakadas); (d) photo (Elif Denel).

another. Instead, present efforts are synthesizing existing scholarship related to two topics: the development of the urban plans of Positano, Amalfi, Atrani, Minori, Maiori, and Cetara, and changes within these cities' maritime façades. The results, so far, are mixed. Amalfi, Atrani, Minori, and Maiori are each prevalent in a variety of sacred and secular sources from the early-Medieval era onwards, whereas Cetara at the eastern border of the Duchy of Amalfi has a minimal presence. All arose between the late 6th century when Amalfi is described as a civitas by Gregory the Great during his reign as Pope - and the late 12th century with the growth of Maiori (Gargano, 1992, p. 22, 1996, p. 522; Migne, 1849 , p. 3, 6, XXIII). Each had similar plans, with intra-moenia and extra-moenia zones demarcated by pairs of defensive walls, but each also had different characters. Cetara was founded by Saracen mercenaries following their expulsion from Naples at the end of the 9th century, and has been predominantly a fishing community since (Camera, 1876, p. 122). Maiori was the agricultural heart of the area until the late 12th century when it began to urbanize, but Minori was the religious centre of the surrounding region, purportedly containing the relics of Saint Trophimena, the patron saint of Amalfi (Gargano, 2001, pp. 15-16; Oldoni, 1971; Braca, 1996, pp. 181-182; Skinner, 2017, pp. 99-100). Atrani, forming an administrative 'conurbation' with Amalfi, housed much of the Amalfitan aristocracy, with houses of the local nobility and the palatine church and palace where the Duchal assembly met (Camera, 1876, p. 56; Gargano, 1992, p. 22, 1995, p. 110; Sangermano, 1981, pp. 60-61; Skinner, 2017, p. 86). Amalfi, in contrast, was the administrative and mercantile hub.

Some elements of these cities' maritime façades were similar. Of their pairs of defensive walls, one was situated near the shoreline in each city. Little is known of the fortification in Cetara, whereas the wall in Atrani apparently stretched westwards approximately $190 \mathrm{~m}$ from the 9thcentury Castrum Leonis to Monte Maggiore (Gargano, 1992, p. 114). More is known of the defensive wall in Maiori, which likely dates to the late 12th century as the town itself was gradually urbanizing (Gargano, 1996, p. 522). Portions of this structure are still extant, extending approximately $200 \mathrm{~m}$ from the steep hill demarcating the eastern edge of the town's alluvial plain to the modern Corso Reginna (Figure 7(a)). At least one cylindrical tower is preserved along this wall, one of which is now converted into the corner of an apartment building, while a small portion of the fossato or defensive ditch is also preserved (Figure 7(b)) In Minori, the wall itself no longer exists although another defensive tower and the fossato are still present along the modern Via Antonio Mancini. Each city reportedly had an arsenal during the Medieval period, although only the example in Amalfi is still preserved (Gargano, 2010, p. 134). The arsenal in Amalfi, argued to be similar to contemporaneous examples in Salerno, Brindisi, and possibly Pisa, was likely constructed in the 11th century and had two parallel bays along its length. Although the original width of the structure $(6.65 \mathrm{~m})$ is still preserved, only the landward half $(44.6 \mathrm{~m})$ of the arsenal's original length is still extant (Gargano, 2010, pp. 133-134).

The partial loss of Amalfi's arsenal is important because it represents the ongoing changes that this maritime landscape is still experiencing. In addition to the disappearance of the arsenal's seaward half, the rivers that formed a key element of these cities' livelihoods prior to the tourism of the 20th century continually impact their built heritage and the coastline. Situated at the outlets of the Canetto, Dragone, Reginna Minor, and Reginna Maior rivers respectively, Amalfi, Atrani, Minori, and Maiori each experience gradual alluviation and intermittent flooding of their river valleys. In 1954, for example, dramatic flooding in this area covered or destroyed much of these cities' historical 

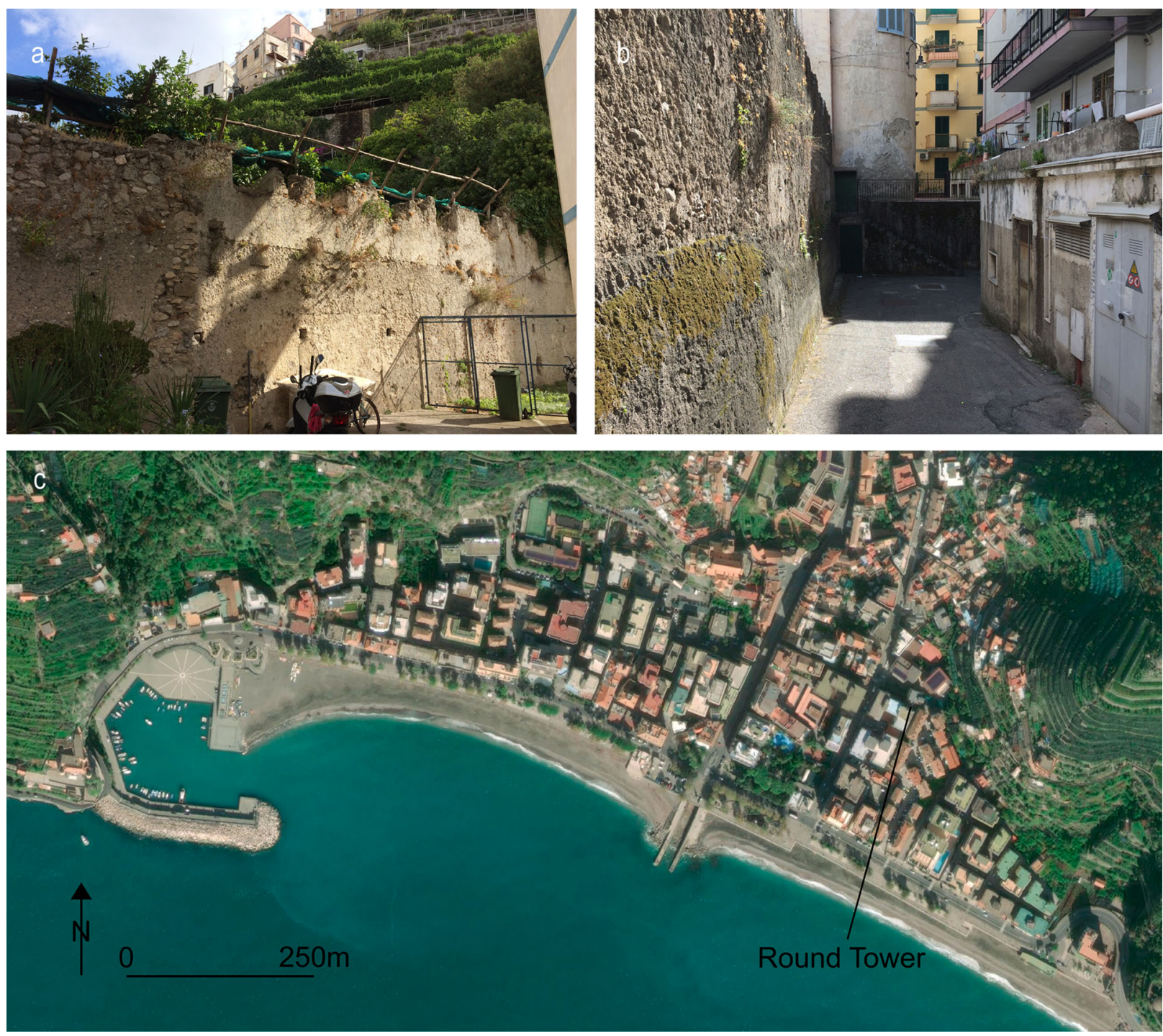

Figure 7. (a) Portion of the medieval defensive wall in Maiori (Vincenzo Capriglione); (b) associated round tower in the background integrated into an apartment building. The adjacent fossato is in front of the wall in the foreground, now converted to a sub-level parking area. (Vincenzo Capriglione); (c) the location of the preserved round tower adjacent to the remnant of Maiori's medieval sea wall.

fabric, leading to the concrete canals as a response to guide and to control the rivers today. The rivers' sedimentary actions change the coastal silhouette as well. The defensive wall in Maiori, theoretically situated on or near the city's beach in the 12th century $\mathrm{AD}$, is now approximately $250 \mathrm{~m}$ from the shoreline (Figure 7(c)). The coastline in Minori is now approximately $130 \mathrm{~m}$ from the estimated location of the city's medieval seawall (Figure 8). Historical documents record other coastal changes near Amalfi and Atrani, as storms and erosion have erased the shared littoral passing around the rocky headland between them (for the storms, see Camera, 1876, p. 33; for the shared beach and its erosion, see Anon., 1892, p. 145; Gargano, 1995, pp. 115116; and Skinner, 2017, pp. 29-30).

\section{Preliminary Conclusions and Goals}

This project along the Amalfi coastline is only beginning. There are many more kilometres of seafloor to survey, more artefacts to document, and much more investigation of this maritime landscape is necessary. Nevertheless, some preliminary conclusions can be drawn. First, it is evident that life in this area may have suffered in the aftermath of the eruption of Vesuvius in $\mathrm{AD} 79$, but activity did not cease. The villa in Minori, for example, was certainly impacted by the eruption but not irreversibly; the numismatic data suggests that activity at some level continued over the following centuries. Similarly, other settlements were built or re-established in Salerno during this period, amphoras in the museum suggest that maritime traffic continued, and Amalfi had recovered substantially by the 6th century, as it was beginning its role as a hub of local power. A second narrative is the ongoing relationship with the sea. As mentioned in the introduction, the adjacent waters are an inescapable part of life in this region yet, over the past centuries, the relationship with the sea has changed. During the prehistoric era, the sea represented a source of sustenance 


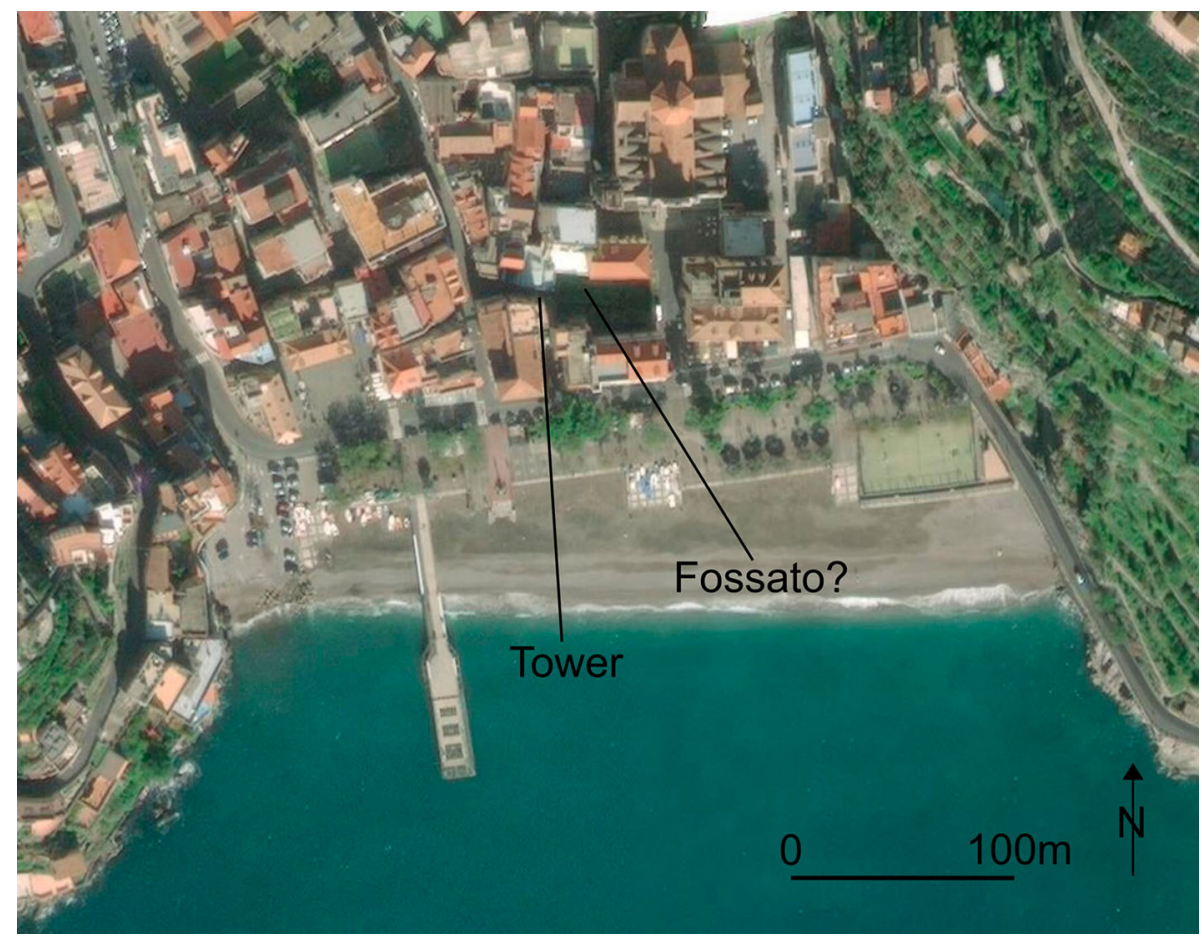

Figure 8. The location of the preserved square tower and possible fossato in Minori, suggesting the location of the city's medieval sea wall.

yet, by the late Republican and early Imperial periods, the villae in Minori, Positano, Li Galli, Isca, and possibly Amalfi suggest it became a source of relaxation and escape. Fishing and the collection of shellfish may have occurred, but it was not necessarily a livelihood. Instead, this coastline was a place to retreat from Rome, yet one not too far away. The defensive towers built in the 13th and 15th centuries, however, highlight a new meaning. Now the sea was a source of danger, a medium that could bring threats. Presently, the sea has changed again as the hotels, luxury homes, and private yachts make it a place of luxury and relaxation.

Plans over the coming seasons will continue this multi-disciplinary effort to decipher and to model this maritime landscape. To test our hypotheses regarding the lack of archaeological material on the seafloor, new surveys in the marine protected area west of Positano are planned in the coming years. Geomorphological studies of the coastline will be expanded to refine our understanding of the relative and actual sea-level change, and to aid the studies of the changing maritime façades of the port cities. Equally important, our efforts will also shift to study and to incorporate the other elements of this maritime landscape: formal and informal place names, the varying cartographies of the sea, local fishing traditions and boatbuilding practices, and ship graffiti and other representations. The coastline from Salerno to Punta Campanella is a maritime landscape par excellence, particularly as - until the middle of the 19th century and the completion of the coastal road - the sea was the best means of communication.

\section{Notes}

1. Although Citarella (1968, p. 535) proposes that it was the terrestrial limits on expansion that prompted Amalfi's maritime dominance, Kreutz (1988) argues the opposite, that Amalfitan maritime activity occurred in spite of environmental detriments.

2. The region has a more extensive tradition of architectural history, however, often in conjunction with the maritime nature of the settlements. See Jinnai and Russo (2011) and Russo (2014) for recent examples.

3. For volcanic ash data from the Bay of Salerno, see Budillon et al. (2006, p. 842, core C836) and Insinga et al. (2008, p. 183, core tS2). Other ash layers from eruptions in 1631 and 1822 have been detected in the Bay of Salerno, but they were not as destructive or dense; see Insinga et al. (2008, p. 184).

4. Museum catalogue numbers of possible Dressel 2-4 amphoras: 924, 947, 954, 962, 963, and 967. Catalogue numbers of possible North African examples: 931 (possible Keay 55), 950 (possible Africana 2A grande or Keay 39), and 959 (Africana 2A grande, or Keay 36 or 57).

5. Museum catalogue number of possible Graeco-Italic amphoras: 928, 935, and 965 (Vb piccolo; see Pugliese 2014); Dressel 1: 947; Dressel 21-22: 960; Lamboglia 2: 949; Almagro 54: 929; Beltran 2A: 925.

6. Museum catalogue number of possible Dressel 2-4 from Kos: 952; Égyptienne Bitronconique 3: 927.

7. Museum catalogue number of possible Late Roman I amphora: 946. See Arthur (1993) for Italian variants. 


\section{Acknowledgements}

Far more many people than can be thanked here have supported this project since 2016. In particular, however, we want to thank Arch. Francesca Casule and Dott.ssa. Silvia Pacifico at the Soprintendenza Archeologia, Belle Arti e Paesaggio per le Province di Salerno e Avellino, Koç University, the Centro di Cultura e Storia Amalfitana, the staff of the villa maritima museum in Minori, Gaetano Milano and Eugenio Angelini in Marina di Praia, and Milena, Rossella and Nicola at l'Altra Costiera. Without the time and help of these individuals and institutions, none of this work could have taken place.

\section{Disclosure Statement}

No potential conflict of interest was reported by the author(s).

\section{Funding}

This work was supported by FP7 People: Marie-Curie Actions [Grant Number 331707] and by the Office of the Vice President for Research and Development, Koç University.

\section{ORCID}

Matthew Harpster (D) http://orcid.org/0000-0002-2571-2413 Athena Trakadas (D) http://orcid.org/0000-0001-5480-351X Chiara Zazzaro (D) http://orcid.org/0000-0002-5677-326X Özge Demirci (D) http://orcid.org/0000-0001-8320-2465 Carlo Donadio (D) http://orcid.org/0000-0001-9582-3058 Luigi Ferranti (D) http://orcid.org/0000-0002-0531-6763 Luca Zavagno (1) http://orcid.org/0000-0003-2450-3182

\section{References}

Aiello, G., Barra, D., Collina, C., Piperno, M., Guidi, A., Stanislao, C., Saracino, M., \& Donadio, C. (2018). Geomorphological and paleoenvironmental evolution in the prehistoric framework of the coastland of mondragone, southern Italy. Quaternary International, 493, 7085. https://doi.org/10.1016/j.quaint.2018.06.041

Albore Livadie, C. (Ed.). (1990). Archeologia a Piano di Sorrento: Ricerche di Preistoria e di Protohistoria nella Penisola Sorrentina: catalogo della mostra. Comune di Piano di Sorrento.

Albore Livadie, C. (2007). La Campania media e la Penisola Sorrento-amalfitana dall' età del Rame all' età del Ferro: alcune situazioni a confront. In F. Senatore, \& M. Russo (Eds.), Sorrento e la Penisola Sorrentina tra Italici, Etruschi e Greci nel conetsto della Campania Antica (pp. 149-175). I quaderni di Oebalus.

Allevato, E., Buonincontri, M., Vairo, M., Pecci, A., Cau, M. A., Yoneda, M., De Simone, G. F., Aoyagi, M., Angelelli, C., Matsuyama, S., Takeuchi, K., \& Di Pasquale, G. (2012). Persistence of the cultural landscape in Campania (Southern Italy) before the AD 472 Vesuvius eruption: Archaeoenvironmental data. Journal of Archaeological Science, 39, 399-406. https://doi.org/10. 1016/j.jas.2011.09.026

Anon. (1892). A handbook for travelers in southern Italy and sicily (9th ed.). John Murray.

Anon. (2006). Progetto archeomar. Censimento dei beni archeologici sommersi delle regioni Campania, Basilicata, Calabria e Puglia. Ministero per i Beni e le Attivita Culturali. Antonioli, F., Cinque, A., Ferranti, L., \& Romano, P. (1994). Emerged and submerged Quaternary marine terraces of Palinuro Cape (southern Italy). Memorie Descrittive Carta Geologica d'Italia, 52, 237-260.

Arthur, P. (1991). Naples: a case of urban survival in the early Middle Ages? Mélanges de l'École francaise de Rome, Moyen-Age, 103(2), 759-784. https://doi.org/10. 3406/antiq.2011.3804

Arthur, P. (1993). Early Medieval Amphoras, the Duchy of Naples and the food supply of Rome. Papers of the British School at Rome, 61, 231-244. https://doi.org/10.1017/ S0068246200009983

Balard, M. (1976). Amalfi et Byzance (Xe-XIIe siècles). Travaux et Mémoires (Centre de recherche d'histoire et civilisation de Byzance, 6, 70-98.

Bencivenga, C., Fergola, L., \& Melillo, L. (1980). Ricerche sulla villa romana di Minori. AION, 3, 131-151.

Bergman, R. (1979). 'Amalfi Sommersa': Myth or Reality? Archivo Storico per le Province Napoletane, 97, 23-30.

Bergman, R. (1991). Byzantine influence and private patronage in a newly discovered medieval church in Amalfi: S. Michele Arcangelo in Pogerola. Architectural History, 50, 421-445.

Braca, A. (1996). Indagini sul patrimonio artistico di Minori. Rassegna del Centro di Cultura e Storia Amalfitana (n.s.), 6, 181-203.

Brancaccio, L., Capaldi, G., Cinque, A., Pece, R., \& Sgrosso, I. (1978). 230Th- 238u dating of corals from a Tyrrhenian beach in Sorrentine Peninsula (southern Italy). Quaternaria, 20, 175-183.

Brancaccio, L., Cinque, A., Romano, P., Rosskopf, C., Russo, F., Santangelo, N., \& Santo, A. (1991). Geomorphology and neotectonics evolution of a sector of the Tyrrhenian flank of the southern Apennines (Region of Naples, Italy). Zeitschrift für Geomorphologie Suppl., 82, 47-58.

Budillon, F., Vicinanza, D., Ferrante, V., \& Iorio, M. (2006). Sediment transport and deposition during extreme sea storm events at the Salerno Bay (Tyrrhenian Sea): comparison of field data with numerical model results. Natural Hazards Earth System Sciences, 6, 839-852. https://doi.org/10.5194/nhess-6-839-2006

Camardo, D. (2008). Le presenze archeologiche dalla preistoria ad epoca classica. In C. P. di Martino, \& M. C. Sorrentino (Eds.), Tramonti la terra operosa. Casali, Pievi, Uomini e Poderi: le Matrici della Vita Rurale in Costa d' Amalfi (pp. 91-101). CCSA Centro di Cultura e Storia Amalfitana.

Camera, M. (1876). Memorie storico-diplomatiche dell'antica città e ducato di Amalfi vol. I. Libreria antiquaria editrice W. Casari. 
Cinque, A., \& Romano, P. (1990). Segnalazione di nuove evidenze di antiche linee di riva in Penisola Sorrentina (campania). Geografia Fisica e Dinamica Quaternaria, 13(1), 23-25.

Cinque, A., \& Putignano, M. (1992). Geomorphology of the continental shelf around the Surrentine Peninsula (Southern Italy). I Conv. di Geol. Sub. e Sottomar. "Geosub", Roma, 5-6 novembre 1991. Giornale di Geologia, 54(2), 165-193.

Citarella, A. (1968). Patterns in Medieval trade: The commerce of Amalfi Before the Crusades. The Journal of Economic History, 28, 531-555. https://doi.org/10.1017/ S0022050700100968

D’Agostino, B. (1968). Marcina? Dialoghi d'Archaeologia, 2, 139-151.

Deposito Minori. 'Villa Minori' Registro Inventario. No date.

De Pippo, T., Donadio, C., \& Sgrosso, A. (1998). Geomorfologia sottomarina di un settore della Penisola Sorrentina (Campania). Geografia Fisica e Dinamica Quaternaria, 21, 103-110.

Espelo, D. (2014). A testimony of carolingian rule? The Codex epistolaris Carolinus as a product of its time. Utrecht University.

Ferranti, L. (2007). Movimenti lenti nell'isola di Capri negli ultimi 124.000 anni. In M. Amitrano, E. Federico, \& C. Fiorentino (Eds.), Conoscere Capri. (vol. 6, pp. 11-37). Capri: Oebalus.

Ferranti, L., Antonioli, F., Mauz, B., Amorosi, A., Dai Pra, G., Mastronuzzi, G., Monaco, C., Orrù, P., Pappalardo, M., Radtke, U., Renda, P., Romano, P., Sansò, P., \& Verrubbi, V. (2006). Markers of the last interglacial sea level high stand along the coast of Italy: Tectonic implications. Quaternary International, 145-146, 30-54. https://doi.org/10.1016/j.quaint.2005.07.009

Ferranti, L., \& Antonioli, F. (2007). Misure del solco tirreniano (MIS 5.5) nell'isola di Capri: valutazione di attività tettonica durante il Pleistocene superiore. Il Quaternario, Italian Journal of Quaternary Sciences, 20(2), 125-136.

Fino, L. (1995). La Costa d'Amalfi e il Golfo di Salerno. Grimaldi and Co.

Gargano, G. (1992). La città davanti al Mare. Aree urbane e storie sommerse di Amalfi nel Medioevo. CCSA Centro di Cultura e Storia Amalfitana.

Gargano, G. (1995). La Topografia di Atrani Medievale. Rassegna del Centro di Cultura e Storia Amalfitana (n.s.), 10, 109-147.

Gargano, G. (1996). I Santi nella toponomastica amalfitana nel Medioevo. In La Chiesa di Amalfi nel Medioevo. Atti del Convegno di Studi per le celebrazioni del Millennio dell'Archidiocesi di Amalfi (987-1987) (Amalfi-ScalaMinori 4-6 dicembre 1987) (pp. 493-536). CCSA (Centro di Cultura e Storia Amalfitana).

Gargano, G. (2001). L'abitato e il territorio. In G. Sangermano (Ed.), Minori Rheginna Minor. Storia, Arte e Culture (pp. 17-26). Salerno.

Gargano, G. (2010). Arsenale e scaria di Amalfi nel contest del Meridione medieval. In D. Blackman, \& M. Costanza
Lentini (Eds.), Ricoveri per Navi Militari nei Porti del Mediterraneo Antico e Medievale (pp. 133-140). Bari.

Greco, E. (1992). Nel Golfo di Napoli: tra Sirene, Sirenusse e Athena. Annali. Sezione di Archeologia e Storia Antica, 14, $161-170$

Guzzo, P. (1992). Il santuario di Punta della Campanella. Atti della giornata di studo: Introduzione, Annali. Sezione di Archeologia e Storia Antica, 14, 151-160.

Iannelli, M. (1991). Una recenta acquisizione archeological a Marina di Vietri: uno spaccato diacronico di un insediamento costiero: secc. I a.C - XIX d.C. Bollettino storico di Salerno e Principato Citra, 1, 5-11.

Iannelli, M. (2011a). La villa romana in località San Leonardo. In A. Campanelli (Ed.), Dopo lo Tsunami Salerno Antica (p. 242). Ministero per i Beni e le Attivita Culturali.

Iannelli, M. (2011b). Evoluzione del territorio. In A. Campanelli (Ed.), Dopo lo Tsunami Salerno Antica (pp. 248-255). Ministero per i Beni e le Attivita Culturali.

Iannelli, M. (2011c). Salerno Centro storico. In A. Campanelli (Ed.), Dopo lo Tsunami Salerno Antica (pp. 263-267). Ministero per i Beni e le Attivita Culturali.

Iannelli, M. (2011d). Via Mercanti, 70. In A. Campanelli (Ed.), Dopo lo Tsunami Salerno Antica (p. 267). Ministero per i Beni e le Attivita Culturali.

Inoue, Y., Baasansuren, J., Watanabe, M., Kamei, H., \& Lowe, D. (2009). Interpretation of pre-AD 479 Roman soils from physiochemical and mineralogical properties of buried tephric paleosoils at Somma Vesuviana ruin, southwest Italy. Geoderma, 152, 243-251. https://doi. org/10.1016/j.geoderma.2009.06.010

Insinga, D., Molisso, F., Lubritto, C., Sacchi, M., Passariello, I., \& Morra, V. (2008). The proximal marine record of SommaVesuvius volcanic activity in the Naples and Salerno bays, Eastern Tyrrhenian Sea, during the last 3 kyrs. Journal of Volcanology and Geothermal Research, 177, 170-186. https://doi.org/10.1016/j.jvolgeores.2007.07.011

Jacoby, D. (2014). Commercio e Navigazione degli Amalfitani nel Mediterraneo Ortientale. Sviluppo e Declino. In B. Figliuolo, \& P. Simbula (Eds.), Interscambi Socio Culturali ed Economici fra le Città Marinare d/'talia e l'Occidente dagli Osservatori Mediterranei (pp. 89-128). CCSA (Centro di Cultura e Storia Amalfitana).

Jacobelli, L. (Ed.). (2017). Nella villa romana di Positano. Archeologia Viva 183, May-June, 9-21.

Jinnai, H., \& Russo, M. (2011). Amalfi. Caratteri dell'edilizia residenziale nel contesto urbanistico dei centri marittimi mediterranei. CCSA (Centro di Cultura e Storia Amalfitana).

Johannowsky, W., Laforgia, E., Romito, M., \& Sampaolo, V. (Eds.). (1986). Le ville romane dell' età imperiale. Società Editrice Napoletana.

Kreutz, B. M. (1988). The ecology of maritime success: The puzzling case of amalfi. Mediterranean Historical Review, 3, 103-113. https://doi.org/10.1080/09518968808569541

Kreutz, B. M. (1996). Before the Normans: southern Italy in the ninth and tenth centuries. University of Pennsylvania Press. 
Lambeck, K., Antonioli, F., Anzidei, M., Ferranti, L., Leoni, G., \& Scicchitano, G. (2011). Sea level change along the Italian coast during the Holocene and projections for the future. Quaternary International, 232, 250-257. https://doi.org/10.1016/j.quaint.2010.04.026

Macedonio, G., Costa, A., \& Folch, A. (2008). Ash fallout scenarios at Vesuvius: Numerical simulations and implications for hazard assessment. Journal of Volcanology and Geothermal Research, 178, 366-377. https://doi.org/10. 1016/j.jvolgeores.2008.08.014

Mangieri, G. L. (1988). La villa romana di Minori: il dato numismatico. Apollo, Bollettino del Musei Provinciali del Salernitano, 6, 165-194.

Mastrolorenzo, G., Palladino, D., Vecchio, G., \& Taddeucci, J. (2002). The $472 \mathrm{AD}$ Pollena eruption of SommaVesuvius (Italy) and its environmental impact at the end of the Roman Empire. Journal of Volcanology and Geothermal Research, 113, 19-36. https://doi.org/10. 1016/S0377-0273(01)00248-7

Migne, J. P. (1849). Patrologia Latina. LXXVII. Sancti Gregori Magni registrum Epistolarum.

Mingazzini, P., \& Pfister, F. (1946). "Surrentum" Forma Italiae. Regio I: Latium e Campania. Florence.

Monumenta Carolina, Bibliotheca Rerum Germanicarum, vol 4. (1864). Wattenbach, W., Dümmler, E., and Jaffé, P. (eds). Berlin.

Oldoni, M. (1971). Agiografia longobarda fra secolo IX e X. La Leggenda di Santa Trofimena. Studi Medievali, 3, Serie XII (2), 582-636.

Pappalardo, U., \& Ciardiello, R. (Eds.). (2005). Guida Geoarcheologica della Costa Campana ad uso dei Naviganti. Valtrend.

Parker, A. J. (1992). Ancient Shipwrecks of the Mediterranean and the Roman Provinces. BAR 580. Oxford.

Pennetta, M., Stanislao, C., D’Ambrosio, V., Marchese, F., Minopoli, C., Trocciola, A., Valente, R., \& Donadio, C. (2016). Geomorphological features of the archaeological marine area of Sinuessa in Campania, southern Italy. Quaternary International, 425, 198-213. https://doi.org/ 10.1016/j.quaint.2016.04.019

Picchetti, G. (1970). Campagna di ricerche subacquee sull'antica Amalfi sommersa (SA). Tempo 46.

Pollone, S., \& Romano, L. (2015). Transformations and permanences of landscape and architecture: The minerva tower of Punta Campanella in the sorrento-Amalfi peninsula. In P. Rodriguez-Navarro (Ed.), Defensive Architecture of the Mediterranean, XV to XVIII centuries (vol. II, pp. 273-280). Editorial Universitat Politècnica de València.

Radmilli, A. M., \& Tongiorgi, E. (1958). Gli scavi nella grotto La Porta di Positano. Contributo all conoscenza del Mesolitico italiano. Rivista di Scienza Prehistoriche, 13, 91-109.

Recchia, P. (2004). Il progetto Archeomar. Notiziario a cura dell'Ufficio Studi, Ministero dei beni e delle attività culturali, Istituto Poligrafico e Zecca Dello Stato, 19, 134-137.
Riccio, A., Riggio, F., \& Romano, P. (2001). Sea level fluctuations during oxygen isotope stage 5: New data from fossil shoreline in the Sorrento Peninsula (Southern Italy). Zeitschrift fur Geomorphologie (N. F.), 45(1), 121-137.

Romano, P., Santo, A., \& Voltaggio, M. (1994). L'evoluzione geomorfologica della piana del fiume Volturno (Campania) durante il tardo Quaternario (Pleistocene medio-superiore-olocene. Il Quaternario, 7, 41-56.

Romito, M. (1986). Una villa rustica romana a Polvica di Tramonti. Rassegna del Centro di Cultura e Storia Amalfitana, 6, 168-178.

Romito, M. (1988). I materiali dell'Antiquarium di Minori (parte prima). Apollo, Bollettino del Musei Provinciali del Salernitano, 6, 119-164.

Romito, M. (1989). I commercio anforario in età romana sulla costiera amalfitana. In Amphores romaines et histoire économique. Dix ans de recherché. Actes du colloque de Sienne (22-24 mai 1986) (pp. 626-628). Ecole française de Rome.

Ronchitelli, A. (1996). Il materiale litico proveniente dalla grotto Sant' Andrea di Amalfi. Apollo, 12, 3-5.

Rota, L. (1995-1996). Ricerca subacquea nel Territorio Salernitano. Bollettino di Archeologia Subacquea, II-III (1-2), 255-256.

Russo, V. (Ed.). (2014). Landscape as Architecture. Identity and conservation of Crapolla cultural site. Nardini Editore.

Sangermano, G. (1981). Caratteri e momenti di Amalfi medievale. Quaderni del Centro di Cultura e Storia Amalfitana / 3. CCSA (Centro di Cultura e Storia Amalfitana).

Santangelo, N., Romano, P., Ascione, A., \& Russo Ermolli, E. (2017). Quaternary evolution of the Southern Apennines coastal plains. A review. Geologica Carpathica, 68(1), 4356. https://doi.org/10.1515/geoca-2017-0004

Shaw, B. D. (2003). A peculiar island: maghrib and mediterranean. Mediterranean Historical Review, 18, 93-125. https://doi.org/10.1080/0951896032000230507

Skinner, P. (2017). Medieval Amalfi and its diaspora 8001250. Cambridge University Press.

Tozzi, C. (1976). Il Mesolitico della Campania. In A. Palma di Cesnola, C. Tozzi, G. Voza, B. D’Agostino, G. Bartolomei, P. Gambassini, R. R. Holloway, G. Colona, P. Messeri, C. Corrain, M. Capitanio, F. Pesarin, \& F. Mallegni (Eds.), Atti della XVII riunione scientifica dell' Instituto Italiano di Prehistoria e Protohistoria in Campania (pp. 33-49). Florence. Instituto Italiano di Preistoria e Protostoria.

Violante, C., Sacchi, M., Cinque, A., Esposito, E., Porfido, S., Toth, T., \& Vittori, E. (2004). Geophysical Investigations and Underwater Archaeology: The debated case of Amalfi Sommersa (Amalfi Coast, Southern Italy). GNGTS, Atti del 23 Convegno Nazionale, no page numbers.

Waelbroeck, C., Labeyrie, L., Michel, E., Duplessy, J. C., McManus, J. F., Lambeck, K. Balbon, E., \& Labracherie, M. (2002). Sea-level and deep-water temperature changes derived from benthic foraminifera isotopic records. Quaternary Science Reviews, 21, 295-305. https://doi. org/10.1016/S0277-3791(01)00101-9 